\title{
Efficacy of Eye Movement Desensitization and Reprocessing (EMDR) Therapy for Children and Adolescents with Post-Traumatic Stress Disorder
}

\author{
Esra Teke $^{1}$ (i) and Selahattin Avşaroğlu ${ }^{1}$ (i)
}

\begin{abstract}
The purpose of the present study is to examine the efficacy of eye movement desensitization and reprocessing (EMDR) therapy for children and adolescents with post-traumatic stress disorder (PTSD). For this purpose, a framework was determined by using findings of the research and explanations at the conceptual level. PTSD is a mental disorder that is experienced after traumatic events, affects individuals cognitively, emotionally, and behaviorally and threatens the integrity of an individual's life. EMDR therapy is a therapy that imaginatively reveals the past or traumatic experiences of the client through eye movements and other bilateral stimuli (two-way sound or tactile stimulus), facilitates information processing processes. Whereas EMDR was initially an approach developed for adults, it was later used for children and adolescents. The fact that it gives positive results in a short time and these positive results continue in follow-up studies has increased the interest in using EMDR for children and adolescents with PTSD. The use of EMDR for children and adolescents has allowed their problems to be resolved in a timely manner and reduced PTSD symptoms. This situation has drawn attention to the importance of using EMDR in the practice of psychological counselors working in school environments, leading places where they work with children and adolescents, and where the first preventive and interventional studies are carried out. Therefore, it is considered that the use of EMDR will be functional in overcoming these negative life experiences of many students who have been directly or indirectly exposed to traumatic experiences during the COVID-19 epidemic period.
\end{abstract}

Keywords: Children, adolescents, eye movement desensitization and reprocessing, EMDR, post-traumatic stress disorder

In the past, while the concept of trauma covered behaviors that harmed only the physical integrity of the individual, it has been defined to include the psychological dimension with the psychoanalytic approach (Jones \& Wessely, 2007; Özen, 2017). In this context, trauma is defined as sudden, uncontrollable and negative life events (Carlson \& Dalenberg, 2000; Hapke et al., 2006). Emotional, cognitive, bodily and behavioral reactions can occur with traumatic events (Kanat \& Özpolat, 2016). Individuals react as they did on the first day of trauma even long time after the traumatic event and this condition becomes chronic referring to as post-traumatic stress disorder (Işıklı \& Keser, 2020). Post-traumatic stress disorder is a serious problem that affects all areas of a person's life (KozaricKovacic, 2008; Y1ldırım \& Arslan, 2021). The severity of this problem indicates the importance of studies on it.

The EMDR therapy is an approach proven to be effective, especially with studies on post-traumatic stress disorder (Beer, 2018; Karadağ et al., 2020; Kemp et al., 2010; Meentken et al., 2020; Rodenburg et al., 2009; Knipe, 2018). EMDR involves the counselor's uncover of the client's past experiences or traumatic experiences through eye movements and other bilateral stimuli (a two-way sound or tactile stimulus). Through this therapy method, individuals are assisted to reprocess their negative experiences in a way that contributes to their emotional health (Denizli, 2008; Y1ldırım \& Maltby, 2021a, 2021b). In addition, such a study also provides an opportunity to understand the structure, existence and maintenance of the changes created by a traumatic event. Because, the duration of the traumatic event, the level of social support perceived by the individual and the age at which the

\footnotetext{
${ }^{1}$ Department of Psychological Counseling and Guidance, Necmettin Erbakan University, Konya, Turkey

Corresponding Author: Esra Teke, Department of Psychological Counseling and Guidance, Faculty of Education, Necmettin Erbakan University, Konya, Turkey.

Email: esradogru1@gmail.com
} 
trauma occurred can be effective factors for giving and maintaining post-traumatic stress disorder reactions (Van der Kolk, 2000).

The understanding that negative experiences in childhood and the problems experienced in the processing of these experiences can manifest themselves in negative life events in the future and cause different psychological disorders in the individual (Özaslan et al., 2021; Y1ldırım et al., 2020), constitutes the basis of the perspective of EMDR therapy on psychological problems (Cengiz \& Peker, 2020). Traumatic events experienced by children can affect their neurological development and all future experiences in their lives. Because all experiences that children deal with are affected by their previous life experiences (Adler-Tapia \& Settle, 2016). Therefore, it is realized that a serious event such as trauma not to cause bigger problems for children and adolescents and that the method used to solve the problems in a timely manner is an important issue. EMDR, which is widely used in trauma, provides faster and more effective results than many treatment interventions (Bisson et al., 2007; Devrim \& Korkmazlar, 2018; Morris-Smith \& Silvestre, 2013). In addition, studies conducted for children and adolescents show that EMDR therapy is a highly effective approach in the treatment of PTSD (Ahmad et al., 2007; Barron et al., 2019; Beer, 2018; Chemtob et al., 2002; Güçlü \& Alkar, 2021; Kemp et al., 2010; Meentken et al., 2020; Rodenburg et al., 2009).

Research reveals that EMDR therapy offered in school-based settings can be an important application to reach large numbers of children and adolescents quickly (Karadağ, 2021). In addition, studies show that the epidemic period can cause negative consequences together with traumatic experiences (Goldmann \& Galea, 2014; King et al., 2020) and that EMDR therapy needs to be used in post-traumatic counseling practices in schools (Denizli, 2008). School psychological counselors, who provide psychological assistance to many students in schools during the epidemic period (Arslan et al., 2020; Arslan et al., 2021), can carry out successful studies in line with this need if they have sufficient knowledge, training and equipment about EMDR therapy. Therefore, in this study, it was aimed to introduce EMDR therapy, which is used in the treatment of children and adolescents with post-traumatic stress disorder, by making use of the relevant literature, and to reveal its effectiveness and relationship with post-traumatic stress disorder.

\section{Post-Traumatic Stress Disorder (PTSD)}

Trauma is used for events that cause the individual to be shaken, hurt and injured in different ways mentally and physically (Jones \& Wessely, 2007; Kokurcan \& Özsan, 2012). Events that leave deep traces in life, cause feelings such as fear and helplessness, and affect the emotions, thoughts and mental states of individuals for a long time are expressed as trauma (Özen, 2017; Yildirim, 2019). The most important aspects in characterizing an event as traumatic are the sudden, uncontrollable and negative perception of that event (Carlson \& Dalenberg, 2000; Hapke et al., 2006).

Individuals can experience traumatic events in three ways (Aker, 2012).

1. The event can directly happen to the individual,

2. The individual can witness such events, help the people who experienced the event,

3. He may learn that such a traumatic event happened to a loved one.

As a result of traumatic events, individuals can give emotional, cognitive, bodily and behavioral reactions (Arslan, 2016; Goodwin \& Stein, 2004; Kanat \& Özpolat, 2016; Tolin \& Foa, 2008). It is normal for these symptoms to appear immediately after traumatic life events (Kessler et al., 2005; Van der Kolk, 2006). While the majority of individuals exposed to traumatic events show post-traumatic stress reactions, a significant proportion of these individuals can overcome this situation without any intervention (Ehlers \& Clark, 2000). The situation of overcoming the negative effects of traumatic events within a few weeks is expressed as acute stress disorder. Individuals who have been exposed to the traumatic event continue to experience these symptoms with the severity of the first day even though it has been a long time (Davison \& Neale, 2004; Deblinger et al., 1999) and this situation becomes chronic, which is expressed as post-traumatic stress disorder (PTSD; Iş1klı \& Keser, 2020). Although traumatic life events can negatively affect both adults and children, childhood is a period of frequent exposure to traumatic events. Depending on the severity of the traumatic events and environmental factors, these experiences can reveal the symptoms of Post-Traumatic Stress Disorder, which do not easily alleviate on their own. Since 
traumatic stress reactions can affect adult life in the long term and cause other accompanying mental disorders, these reactions should be considered in childhood (Oflaz, 2015).

In DSM-5, as in adults, PTSD symptoms of children include re-experiencing the traumatic event with involuntary thoughts and images, avoiding or reducing the level of response to stimuli related to the event, negative changes in thoughts and emotions, and increased arousal (APA, 2013). Besides, traumatic stress reactions seen in children are very diverse. Traumatic stress reactions manifest themselves with different behavioral characteristics depending on the severity and type of the event, the developmental characteristics of the child, gender, age, family history and cultural background (Oflaz, 2015). For this reason, it is important to consider the developmental characteristics of children in diagnosis and treatment studies.

\section{Treatment of Post-Traumatic Stress Disorder}

Trauma is defined as sudden, uncontrollable and negative life events (Carlson \& Dalenberg, 2000; Hapke et al., 2006). Emotional, cognitive, bodily and behavioral reactions can occur with traumatic events (Kanat \& Özpolat, 2016). Individuals react as they did on the first day of trauma even long time after the traumatic event and this condition becomes chronic referring to as post-traumatic stress disorder (Ișıklı \& Keser, 2020). Post-traumatic stress disorder is a serious problem that affects all areas of a person's life (Kozaric-Kovacic, 2008; Y1ldırım \& Arslan, 2021). The severity of this problem indicates the importance of studies on it.

PTSD has a chronic nature and can cause personal and social burdens in the life of the individual. When adequate treatment studies are not carried out in this regard, the power of recovery may decrease (Kılınç et al., 2017). In the literature, drug therapy and psychotherapy are seen as the two main intervention approaches in PTSD treatment studies, and it is accepted that the application of these two methods increases the success level and functionality of treatment studies (Bilen, 2019; Clark \& Taylor, 2009). Besides, it is possible to see studies in metaanalysis studies showing that the most effective intervention methods for post-traumatic stress disorder are traumafocused therapies (Bisson et al., 2007). Studies conducted in this context reveal that trauma-focused cognitive behavioral therapy (CBT) and EMDR therapy are the most supported psychotherapy methods (Seidler et al., 2006; Taylor et al., 2003). Many studies conducted for children and adolescents in recent years have shown that EMDR therapy is a very effective approach in traumatic stress disorder (Barron et al., 2019; Beer, 2018; Güçlü \& Alkar, 2021; Meentken et al. 2020).

\section{EMDR}

EMDR is a type of confrontation therapy that includes cognitive restructuring, the use of rapid and rhythmic eye movements, and other bilateral simulations used in the treatment of clients experiencing traumatic stress (Corey, 2008). This therapy method developed by Shapiro provides simultaneous cognitive, emotional and somatic information processing by accessing the cognitive, emotional and somatic aspects of trauma memories (Gomez, 2020). EMDR is a highly effective and reliable therapy approach in the intervention of traumatic memories (Kavakç1 et al., 2010; Knipe, 2018; Van Etten \& Taylor, 1998).

In the EMDR approach, it is stated that traumatic memories are stored inappropriately in the memory. Storing memories in this way can cause individuals to give dysfunctional responses to triggering situations. In this context, EMDR enables the reprocessing of traumatic memories stored in their original form, such as unprocessed thoughts and sensations. Thus, as a result of reprocessing frozen memories, it allows depersonalization and adaptive functionality against disturbing situations (Shapiro \& Maxfield 2002). EMDR was developed to help clients to overcome post-traumatic stress disorders. It is applied to very different groups such as children, couples, victims of sexual abuse, war veterans, crime victims, victims of rape, accident victims, individuals receiving treatment for anxiety, panic, depression, grief, addiction, and phobia (Corey, 2008).

\section{Phases of EMDR Therapy}

EMDR therapy targets unprocessed memories including negative emotions, sensations and beliefs (Shapiro, 2017). In this context, standard EMDR therapy is carried out in eight phases (Solomon \& Shapiro, 2008; Shapiro, 1999). While the first two phases are applied in one session, the number of sessions for the other phases may differ (Kavakçı et al., 2010; Shapiro, 2018).

- First phase (History taking phase): At this phase, a history suitable for EMDR therapy is taken, the suitability of the client for EMDR therapy is evaluated, and a treatment study is planned (Kavakç1, 2014). 
- Second phase (Preparing the Client for treatment): This phase includes preparing the client for the process and stabilizing it. Establishing a therapeutic relationship, determining achievable expectations, informing the client about their symptoms, teaching the client self-soothing techniques constitute the content of this phase (Kavakçı et al., 2010). The focus of this phase is the development and improvement of personal resources on issues such as safety and self-control before working on traumatic memories (Shapiro \& Maxfield, 2002). In this context, it is important to carry out comprehensive resource development studies such as safe place, breathing technique, and to teach self-control techniques (Korn \& Leeds, 2002; Shapiro, 2017).

- Third phase (Assessment phase): This phase begins with the processing of the traumatic memory. The client identifies a picture that represents the intended memory. The client is asked to identify the perceptions, cognitions, emotions and body sensations that emerge with this picture. When the client looks at the target picture, the functional thought of the client is determined by asking which positive cognition s/he wants to have. The validity (Voc) of the identified positive cognition is scored between 1 and 7. The client's definition of negative cognition can awaken strong emotions by activating memory networks. In this context, the client is asked to evaluate the subjective disturbance level (Sud) between 0 and 10. Finally, the client is asked to determine where in his body he feels this disturbance most (Kavakç1 et al., 2010).

- Fourth phase (Desensitization phase): It is the phase of desensitization of the unprocessed negative memory through bidirectional stimulation. At this phase, the person is asked to focus on the picture s/he has chosen, his/her negative cognition, emotions and what s/he feels in his body, and bidirectional stimulation is started. This process is continued until the subjective disturbance level of the client reaches zero. It includes a complete assimilation of memories by fully processing all channels (Shapiro \& Laliotis, 2011).

- Fifth phase (Installation phase): This phase starts with the individual's ability to recall the targeted memory without disturbance, and at this phase, it is aimed to place the targeted positive cognition and increase its strength (Shapiro, 1999).

- Sixth phase (Body scanning phase): When the target moment is visualized, body scanning is performed to evaluate whether there is any unprocessed disturbance (Kavakç1, 2014). The procedure is not complete until the client is able to think through the disturbing memory without feeling bodily tension. If the client reports any negative feelings, these are targeted for processing until the tension is relieved (Shapiro \& Maxfield 2002).

- Seventh phase (Closure phase): In this phase, the therapist evaluates whether the processing has been adequately achieved. If s/he feels that there is not enough processing, s/he uses the self-soothing techniques applied in the second phase. In this context, clients are informed that processing can continue between sessions (Kavakçı et al., 2010).

- Eighth phase (Reevaluation phase): In this phase, the therapist checks whether the client has adequately integrated the targeted memories and associated states (image, negative and positive cognition, body sensations). Therapist checks again whether the targets worked in the previous session have been resolved by taking the "Sud" level. When the client focuses on negative cognition and image, it is checked whether there is any tension or unusual sensation in his/her body. The fact that the client shows discomfort is an indication that the processing has not been completed (Kavakçı, 2014).

\section{Use of EMDR for Children and Adolescents}

Children are affected in different ways by the events they experience depending on their age and developmental characteristics, and they react differently to these events. Especially in traumas that develop at an early age, children have difficulty in expressing their emotions verbally and cannot manage their emotions in a healthy way. Since they are in the process of development physiologically, neurologically, cognitively, emotionally and socially, their way of presenting the problem and their interventions towards the problem are different from adults. For this reason, it is important to make evaluations and interventions in accordance with their developmental characteristics in studies with children. (Korkmazlar \& Uğurlu, 2021). While applying EMDR therapy, these issues should be considered, 
and appropriate arrangements should be made. These regulations also affect the success of the intervention to be applied to children (Gomez, 2012).

In the course of working with children and adolescents, information is obtained from both the child and the parent separately during the history taking and treatment planning stages. The messages that the child presents from the area of emotion, sensation and cognition and from the body language are noted. During the preparation phase, the child's emotional management and resources are evaluated. The stop sign is taught and safe/calm ground work is done. Pictures of this place can be drawn. In the assessment phase, children determine the picture by drawing a picture, working on a sand tray or using methods such as play therapy. While determining other items at this stage, concretizing methods suitable for the age and cognitive capacity of the children are used. In the desensitization phase, shorter sets of BLS are administered for children. BLS type and speed need to be changed more frequently. In the installation phase, methods such as VoC bridge are used. During the body scanning phase, young children are shown how to scan the body using toys. The X-ray device sample can be used. In the closure phase, attention is paid to the client's stable completion of the session. For this purpose, additional techniques such as containers, games and stories can be used in addition to the safe place exercise. During the reevaluation, the specific target and clinical changes between sessions are evaluated (Adler-Tapia \& Settle, 2016). EMDR sessions with children are approximately 45 minutes. This may vary according to the age levels of the children. Children's attention and focus periods are short and additional work may be required (Shapiro, 2018). For this reason, different techniques such as play therapy, family therapy and art therapy can be used in EMDR practices with children and adolescents, considering their needs and development levels (Korkmazlar \& Uğurlu, 2021).

\section{Efficacy of EMDR for Children and Adolescents}

Studies have shown that EMDR can be used for adults (Bisson \& Andrew, 2007; Seidler \& Wagner, 2006) and for children (Ahmad et al., 2007; Barron et al., 2019; Beer, 2018; Kemp et al., 2010; Meentken et al. 2020; Rodenburg. et al., 2009) it is an effective therapy for the treatment of PTSD. Although face-to-face therapy is an ideal in therapy with children, the epidemic period has made online psychotherapy studies mandatory. Effective studies were carried out with children and adolescents in this period (Korkmazlar \& Uğurlu, 2021). In this context, it is noticed that EMDR studies conducted with children and adolescents both face-to-face and online show effective results (Korkmazlar et al., 2020).

Yurtsever et al. (2018) evaluated the effectiveness of EMDR in the treatment of PTSD symptoms and depressive symptoms among child and adult refugees and reported that $60 \%$ of the participants did not have symptoms after EMDR. Karadağ et al. (2019) in their study evaluating the effectiveness of EMDR for children and adolescents found that $53 \%$ of the participants initially showed severe PTSD symptoms, while this rate decreased to $13 \%$ after EMDR treatment. Ahmad et al. (2007) observed a significant decrease in the children's re-experiencing symptoms as a result of their randomized controlled study conducted on two groups of children diagnosed with PTSD. In the study conducted by Hensel (2009) with 36 children and adolescents between the ages of 1-18, it was observed that there was a positive and rapid change in children as a result of six-month follow-up after EMDR. In addition, difference was not found between the responses of preschool and school-aged children to treatment in this study. In a study conducted by Karadağ (2020) with adolescent girls who were victims of abuse, it was reported that after 3 sessions of EMDR group therapy, the average score of the participants on the trauma scale decreased from $53.5 \%$ to $39.40 \%$, and PTSD and accompanying symptoms improved. These and similar studies have revealed that EMDR is an effective therapy for children and adolescents (Devrim \& Korkmazlar, 2018; Kavakç1, 2010; Kemp et al., 2010).

\section{EMDR Applications in School}

The effects of childhood traumas can be devastating, and the negative effects of these events may continue in adulthood (Dunn et al., 2017). Since this situation causes the problem to become chronic, it also reduces the impact of studies conducted in later adulthood (Van der Kolk et al., 2007). Studies also reveal the prevalence of mental health problems among children and adolescents (Masoom et al., 2020; Özaslan \& Y1ldırım, 2021), and thus an increased need for therapeutic interventions (Kokanović \& Hasanović, 2018). This situation draws attention to the importance of reaching children and adolescents quickly and helping them find solutions to their problems.

Schools are institutions that allow children and adolescents to be reached quickly. Children spend most of their time at schools (Arslan, 2018). Every new change and symptom shown by them can be easily noticed by education 
professionals (Atkinson et al., 2014). In addition, schools have an important role in detecting family dysfunctions, reaching the family, following the development of the family, and reducing the risks of problems with well-timed responses (Arslan, 2017; Arslan \& Burke, 2021; Fisher, 2011). Studies reveal that providing EMDR therapy in a school-based setting can be an important practice to reach a large number of children quickly (Karadağ et al., 2021). Since EMDR therapy targets not only traumatic memories but also current problems and incompatibilities that are predicted to be related to trauma (Shapiro, 2007), it will be beneficial to use it actively in schools (Chemtob et al., 2002).

Although psychological counselors working in schools carry out various studies on both traumatic events and current problems considering the developmental level of children, studies reveal that there is a need for the use of EMDR therapy in psychological counseling practices (Denizli, 2008). It is also seen that the studies on EMDR applications in schools are limited. However, it is also noticed that the studies carried out give effective results (Fernandez et al., 2003). In this context, Karadağ et al. (2021) evaluated the mental health status of children attending a primary school and not directly affected by the epidemic. As a result of the study, they found the level of post-traumatic stress in children to be high during the COVID-19 epidemic and determined self-help intervention derived from EMDR was an effective psychosocial intervention tool. Fernandez et al. (2004) conducted school based EMDR interventions for 236 children in their study. They found that the school based EMDR intervention was effective in reducing PTSD symptoms that impair school function. Chemtob et al. (2002) conducted their research on disaster-related PTSD symptoms in children with a school-based method. As a result of the study, they observed a decrease in children's PTSD symptoms. Kokanović and Hasanović (2018) presented the case of four adolescents in their study. Some of the main symptoms of cases are refusal to fulfill school obligations and a marked decline in school grades. It was observed that there was a significant decrease in the symptoms of the cases after the EMDR sessions. This study showed that traumatic events can cause symptoms related to high levels of anxiety and impairment in daily functioning. In the study, it was also emphasized that if the symptoms are not noticed and treated professionally, the initial reactions can turn into symptoms at a more advanced level. This result also sheds light on the importance of first-hand and rapid interventions to children in schools.

\section{Conclusion}

Shapiro carried out his first observations with EMDR therapy in 1987 and published his first controlled study in 1989 (Shapiro, 2017). In this context, it can be claimed that EMDR therapy is a relatively new psychotherapy model compared to other approaches (Novo Navarro et al., 2018). When the studies on EMDR therapy are examined, it is possible to find many studies on the subject in the foreign literature, but it is seen that these studies are less in the domestic literature. Nonetheless, it is also possible to state that studies on EMDR therapy have shown a general increase in recent years. However, studies on children and adolescents are not sufficient (Moreno-Alcázar et al., 2017, Valiente-Gómez et al., 2017). Nevertheless, childhood is a period in which traumatic events are frequently exposed. Depending on the severity of the traumatic events and environmental factors, these experiences can reveal the symptoms of PTSD, which do not ease spontaneously (Oflaz, 2015). For this reason, care should be taken about the effects of negative life events on children.

Many recent studies report that the current epidemic has negative effects on children's mental health (Arslan \& Y1ldırım, 2021; King et al., 2020). In addition, it is stated in studies that it is impossible for children not to be psychologically affected by the epidemic, which causes many traumatic experiences (Fegert et al., 2020). In such an environment, children may feel vulnerable, their daily routines may be disrupted, and they may have difficulty in managing themselves, their emotions and thoughts. If adults who will protect and watch over them cannot show healthy reactions, it is inevitable for children to show signs of post-traumatic stress disorder (Korkmazlar et al., 2020). Research indicates the prevalence of mental health problems among children and adolescents (Alshehri et al., 2020), and thus an increased need for therapeutic interventions. (Kokanovic \& Hasanović, 2018). However, research also reveals that EMDR therapy offered in school-based settings can be an important application to reach a large number of children and adolescents quickly (Karadağ, 2021). Because schools are institutions that allow children and adolescents to be reached quickly. Every new change and symptom shown by them can be easily noticed in school environments (Atkinson et al., 2014; Fisher, 2011).

Psychological counselors working in schools can carry out various studies on both traumatic events and current 
problems, considering the developmental level of children. If school counselors have appropriate psychotherapeutic training and are in direct, daily contact with children, they can notice small changes in children, respond adequately and immediately, and contribute to the reduction and disappearance of their symptoms (Kokanović \& Hasanović, 2018). In this context, it will be functional for school counselors to benefit from EMDR therapy in their interventions for children and adolescents with traumatic symptoms. Research points out that EMDR is effective in improving PTSD symptoms in children and adolescents (Beer, 2018; Kemp et al., 2010; Meentken et al., 2020; Rodenburg et al., 2009; Karadag et al., 2020).

When the studies in the literature are examined; Karadağ et al. (2021) found that self-help intervention for children derived from EMDR was effective in reducing PTSD symptoms during the COVID-19 epidemic period. Yurtsever et al. (2018) in the treatment of PTSD symptoms and depressive symptoms among child and adult refugees, Fernandez et al. (2004) in reducing PTSD symptoms that impair school function, Ahmad et al. (2007) conducted a randomized controlled study on two groups of children diagnosed with PTSD. Barron et al. (2019) found that EMDR is an effective therapy method in their study on children with PTSD. Considering that there may be many traumatic events and experiences with different characteristics on the basis of PTSD, it can be claimed that there is a need to continue studies on this subject with different cases and events and to compare the results. In this context, studies and fields of study can be increased by considering this issue in studies related to EMDR.

Studies in the literature reveal that it is possible to use EMDR as a short-term and effective approach after any traumatic experience (Denizli, 2008). In this context, EMDR is seen as an approach that can be applied in a shortterm and effective way in schools where many students need to be reached. However, studies on the effectiveness of EMDR in schools are very limited. For this reason, EMDR therapy studies for children and adolescents in schools should be increased and its effectiveness should be tested.

The use of EMDR can be functional in overcoming these negative life experiences of many students who have been directly or indirectly exposed to traumatic experiences during the current epidemic period. In this context, individual and group-based EMDR applications can be carried out in schools. Written and visual materials can be developed for applications.

School counselors have a significant impact on psychological interventions for children and adolescents. However, school counselors, who have to deal with too many students, often need a short and quick intervention. School counselors need to complete EMDR therapy training and supervision in order to be able to effectively intervene with children and adolescents who are directly or indirectly exposed to many traumatic events. In order to complete them, necessary facilities (such as permits, fees, accommodation) should be provided and they should be encouraged to use them in the field.

\section{Compliance with Ethical Standards}

\section{Ethical Standards}

This study did not require Ethics Board approval because it does not involve human or animal subjects.

\section{Author Contributions}

The authors developed the concept for this manuscript, carried out the literature search, wrote the manuscript, and proofread it.

\section{Declaration of Conflicting Interests}

The author(s) declared no potential conflicts of interest with respect to the research, authorship, and/or publication of this article.

\section{Funding}

The author(s) received no financial support for the research, authorship, and/or publication of this article. 
Received: August 24, 2021

Accepted: September 23, 2021

\section{References}

Published Online: September 30, 2021

Adler-Tapia, R., \& Settle, C. (2016). EMDR and the art of psychotherapy with children: Infants to adolescents. Springer Publishing Company.

Ahmad, A., Larsson, B., \& Sundelin-Wahlsten, V. (2007). EMDR treatment for children with PTSD: Results of a randomized controlled trial. Nordic Journal of Psychiatry, 61(5), 349-354. https://doi.org/10.1080/08039480701643464

Aker, A. T. (2012). Temel sağlık hizmetlerinde ruhsal travmaya yaklaşım. (TREP) Türkiye Psikiyatri Derneği Ruhsal Travma ve Afet ÇB Yayını.

Alshehri, N. A., Y1ldırım, M., \& Vostanis, P. (2020). Social Support and Mental Health Problems. Arab Journal of Psychiatry, 31(2), 130-143.

APA (2013). Diagnostic and statistical manual of mental disorders. American Psychiatric Association.

Arslan, G. (2016). Psychological maltreatment, emotional and behavioral problems in adolescents: The mediating role of resilience and self-esteem. Child Abuse \& Neglect, 52, 200-209.

Arslan, G. (2017). Psychological maltreatment, coping strategies, and mental health problems: A brief and effective measure of psychological maltreatment in adolescents. Child Abuse \& Neglect, 68, 96-106.

Arslan, G. (2018). School-based social exclusion, affective wellbeing, and mental health problems in adolescents: A study of mediator and moderator role of academic self-regulation. Child indicators research, 11(3), 963980.

Arslan, G., \& Burke, J. (2021). Positive education to promote flourishing in students returning to school after COVID-19 closure. Journal of School and Educational Psychology, 1(1), 1-5. https://doi.org/10.47602/josep.v1i1.3

Arslan, G., \& Yıldırım, M. (2021). Perceived risk, positive youth-parent relationships, and internalizing problems in adolescents: Initial development of the meaningful school questionnaire. Child Indicators Research, 1-19.

Arslan, G., Yıldırım, M., \& Zangeneh, M. (2021). Coronavirus anxiety and psychological adjustment in college students: Exploring the role of college belongingness and social media addiction. International Journal of Mental Health and Addiction, 1-14.

Arslan, G., Yıldırım, M., Karataş, Z., Kabasakal, Z., \& Kılınç, M. (2020). Meaningful living to promote complete mental health among university students in the context of the COVID-19 pandemic. International Journal of Mental Health and Addiction, 1-13.

Atkinson, C., Squires, G., Bragg, J., Muscutt, J., \& Wasilewski, D. (2014). Facilitators and barriers to the provision of therapeutic interventions by school psychologists. School Psychology International, 35(4), 384-39. https://doi.org/10.1177/0143034313485849

Barron, I. G., Bourgaize, C., Lempertz, D., Swinden, C., \& Darker-Smith, S. (2019). Eye movement desensitization reprocessing for children and adolescents with posttraumatic stress disorder: A systematic narrative review. Journal of EMDR Practice and Research, 13(4), 270-283. http://dx.doi.org/10.1891/19333196.13.4.270

Barron, I. G., Bourgaize, C., Lempertz, D., Swinden, C., \& Darker-Smith, S. (2019). Eye movement desensitization reprocessing for children and adolescents with posttraumatic stress disorder: A systematic narrative review. Journal of EMDR Practice and Research, 13(4), 270-283. http://dx.doi.org/10.1891/19333196.13.4.270

Beer, R. (2018). Efficacy of EMDR therapy for children with PTSD: A review of the literature. Journal of EMDR Practice and Research, 12(4), 177-195. http:// dx. doi. org/ 10. 1891/ 1933- 3196. 12.4.177

Bilen, D. (2019). Suriyeli mültecilerde travma sonrast stres bozukluğu ve yaşam doyumu düzeyinin çeşitli değişkenlere göre incelenmesi [Yayımlanmamış yüksek lisans tezi]. Çağ Üniversitesi.

Bisson, J. I., Ehlers, A., Matthews, R., Pilling, S., Richards, D., \& Turner, S. (2007). Psychological treatments for chronic post-traumatic stress disorder: Systematic review and meta-analysis. The British Journal of Psychiatry, 190(2), 97-104. https://doi.org/10.1192/bjp.bp.106.021402 
Carlson, E. B., \& Dalenberg, C. J. (2000). A conceptual framework for the impact of traumatic experiences. Trauma, Violence, \& Abuse, 1(1), 4-28. https://doi.org/10.1177/1524838000001001002

Cengiz, S., \& Peker, Â. (2020). Obsesif kompulsif bozuklukta EMDR terapinin etkisi: Olgu sunumu. Türk Eğitim Bilimleri Dergisi, 18(1), 201-217. https://doi.org/10.37217/tebd.666962

Chemtob, C. M., Nakashima, J., Carlson, J. G. (2002). Brief treatment for elementary school children with disasterrelated posttraumatic stress disorder: A field study. Journal of Clinical Psychology, 58(1), 99112. https://doi.org/10.1002/jclp.1131

Clark, D. A., \& Taylor, S. (2009). The transdiagnostic perspective on cognitive-behavioral therapy for anxiety and depression: New wine for old wineskins?. Journal of Cognitive Psychotherapy, 23(1), 60-66. https://doi.org/10.1891/0889-8391.23.1.60

Corey, G. (2008). Psikolojik danışma, psikoterapi kuram ve uygulamaları (T. Ergene, Çev.). Mentis (Orijinal eserin basım tarihi 2005).

Davison, G. C., \& Neale, J. M. (2004). Anormal psikolojisi (7. Baskı). (İ. Dağ, Çev.). Türk Psikologlar Derneği Yayınları (Orijinal eserin basım tarihi 1998).

Deblinger, E., Steer, R. A., \& Lippmann, J. (1999). Two-year follow-up study of cognitive behavioral therapy for sexually abused children suffering post-traumatic stress symptoms. Child Abuse \& Neglect, 23(12), 13711378. https://doi.org/10.1016/S0145-2134(99)00091-5

Denizli, S. (2008). Göz hareketleriyle duyarsızlaştırma ve yeniden işleme: Yaklaşımın etkililiği ve bugünkü durumu. Ege Ë̆itim Dergisi, 9(2), 79-92. https://dergipark.org.tr/tr/pub/egeefd/issue/4911/67252

Devrim, E., \& Korkmazlar, Ü. (2018, Nisan, 7-8). Soma maden kazasında babasını kaybeden bir çocuk ile yapılan EMDR uygulamaları [Sözlü sunum]. 4. EMDR sempozyumunda, İstanbul, Türkiye.

Dunn, E. C., Nishimi, K., Powers, A., \& Bradley, B. (2017). Is developmental timing of trauma exposure associated with depressive and post-traumatic stress disorder symptoms in adulthood? Journal of Psychiatric Research, 84, 119-127. https://doi.org/10.1016/j.jpsychires.2016.09.004

Ehlers, A., \& Clark, D. M. (2000). A cognitive model of posttraumatic stress disorder. Behaviour Research and Therapy, 38(4), 319-345. https://doi.org/10.1016/S0005-7967(99)00123-0

Fegert, J. M., Vitiello, B., Plener, P. L., \& Clemens, V. (2020). Challenges and burden of the Coronavirus 2019 (COVID-19) pandemic for child and adolescent mental health: A narrative review to highlight clinical and research needs in the acute phase and the long return to normality. Child and Adolescent Psychiatry and Mental Health, 14(20), 1-11. https://doi.org/10.1186/s13034-020-00329-3

Fernandez, I., Gallinari, E., \& Lorenzetti, A. (2004). A school-based EMDR intervention for children who witnessed the Pirelli Building airplane crash in Milan, Italy. Journal of Brief Therapy, 2(2), 129-136.

Fisher, A. (2011). Depressive and other symptoms of emotional disorders in adolescents. International Journal of Social Psychiatry, 57(1), 22-39. https://doi.org/10.1177/0020764010396695

Goldmann, E., \& Galea, S. (2014). Mental health consequences of disasters. Annual Review of Public Health, 35, 169-183. https://doi.org/10.1146/annurev-publhealth-032013-182435

Gomez, A. M. (2012). EMDR therapy and adjunct approaches with children: Complex trauma, attachment, and dissociation. Springer Publishing Company.

Goodwin, R. D. \& Stein, M. B. (2004). Association between childhood trauma and physical disorders among adults in the United States. Psychological Medicine, 34(3), 509-520. https://doi.org/10.1017/S003329170300134X

Güçlü, A., \& Alkar, Ö. Y. (2021). Travma sonrası stres bozukluğunda EMDR uygulamalarının etkililiğine ilişkin çalışmaların gözden geçirilmesi. Türk Psikoloji Yazıları, 24(47), 62-75 Doi: 10.31828/tpy1301996120210108m000032

Hapke, U., Schumann, A., Rumpf, H. J., John, U., \& Meyer, C. (2006). Post-traumatic stress disorder. European Archives of Psychiatry and Clinical Neuroscience, 256(5), 299-306. https://doi.org/10.1007/s00406-0060654-6

Hensel, T. (2009). EMDR with children and adolescents after single-incident trauma. Journal of EMDR Practice and Research, 3(1), 2-9. Doi: 10.1891/1933-3196.3.1.2

Işıklı S., \& Keser E. (2020). Travma sonrası stres bozukluğunda duygular ve duygu düzenleme. S. Vatan (Ed.), Duygu düzenleme (1. Bask1, s. 55-63). Türkiye Klinikleri.

Jones, E., \& Wessely, S. (2007). A paradigm shift in the conceptualization of psychological trauma in the 20th century. Journal of Anxiety Disorders, 21(2), 164-175. https://doi.org/10.1016/j.janxdis.2006.09.009 
Kanat, B. B., \& Özpolat, A. G. Y. (2016). Kanser hastalarında travma sonrası büyüme kavramı. Turkish Journal of Clinics and Laboratory, 7(4), 106-110. https://dergipark.org.tr/en/pub/tjcl/issue/26304/286720

Karadağ, M. (2020). Cinsel istismar mağduru kompleks travma sonrası stres bozukluğu olan kız ergenlerde grup EMDR uygulaması. Psikiyatride Güncel Yaklaşımlar, 12(1), 1-6. https://doi.org/10.18863/pgy.686609

Karadağ, M., Gökçen, C., \& Sarp, A. S. (2019). EMDR therapy in children and adolescents who have post-traumatic stress disorder: A six-week follow-up study. International Journal of Psychiatry in Clinical Practice, 24(1), 77-82. https://doi.org/10.1080/13651501.2019.1682171

Karadağ, M., Topal, Z., Ezer, R. N., \& Gökçen, C. (2021). Use of EMDR-derived self-help intervention in children in the period of COVID-19: A randomized-controlled study. Journal of EMDR Practice and Research. http://dx.doi.org/10.1891/EMDR-D-20-00054

Kavakçı, Ö. (2014). Ruhsal travma tedavisi için EMDR. HYB Yayıncılık.

Kavakçı, Ö., Doğan, O., \& Kuğu, N. (2010). EMDR (Göz hareketleri ile duyarsızlaştırma ve yeniden işleme): Psikoterapide farklı bir seçenek. Düşünen Adam-Psikiyatri ve Nörolojik Bilimler Dergisi, 23(3), 195-205. Doi: 10.5350/DAJPN2010230307

Kemp, M., Drummond, P., \& McDermott, B. (2010). A wait-list controlled pilot study of eye movement desensitization and reprocessing (EMDR) for children with post-traumatic stress disorder (PTSD) symptoms from motor vehicle accidents. Clinical Child Psychology and Psychiatry, 15(1), 5-25. https://doi.org/10.1177/1359104509339086

Kessler, R. C., Berglund, P., Demler, O., Jin, R., Merikangas, K. R., \& Walters, E. E. (2005). Lifetime prevalence and age-of-onset distributions of DSM-IV disorders in the National Comorbidity Survey Replication. Archives of General Psychiatry, 62(6), 593-602. Doi:10.1001/archpsyc.62.6.593

Kılınç, G., Yıldız, E., \& Harmancı, P. (2017). Toplumsal travmatik olaylar ve aile ruh sağlığı. Turkiye Klinikleri Psychiatric Nursing-Special Topics, 3(2), 182-188.

King, D. L., Delfabbro, P. H., Billieux, J., \& Potenza, M. N. (2020). Problematic online gaming and the COVID19 pandemic. Journal of Behavioral Addictions, 9(2), 184-186. https://doi.org/10.1556/2006.2020.00016

Knipe, J. (2018). EMDR toolbox: Theory and treatment of complex PTSD and dissociation. Springer Publishing Company.

Kokanović, I., \& Hasanović, M. (2018). Would the well-timed use of EMDR therapy in the school system save the mental health of youth? Case reports. Psychiatria Danubina, 30(5), 276-281.

Kokurcan, A., \& Özsan, H. H. (2012). Travma kavramının psikiyatri tarihindeki seyri. Kriz Dergisi, 20(1), 19-24. https://doi.org/10.1501/Kriz_0000000330

Korkmazlar, Ü. \& Uğurlu, B. A. (2021). Çocuklarla online EMDR. M. Teber (Ed.), Çocuklarla online terapi (s.4965). Yenikapı Yayınları.

Korkmazlar, Ü., İnci-İzmir S. B., \& İpçi, M. (2020). Pandemi dönemi travmalarda çocuklar ve ailelerle EMDR uygulamaları. E. S. Ercan, Ç. Yektaş, A. E. Tufan, \& Ö. Bilaç (Ed.), COVID-19 pandemisi ve çocuk ve ergen ruh sağgl ̆̆g (1. Bask1, s. 132-5). Türkiye Klinikleri.

Korn, D. L., \& Leeds, A. M. (2002). Preliminary evidence of efficacy for EMDR resource development and installation in the stabilization phase of treatment of complex posttraumatic stress disorder. Journal of Clinical Psychology, 58(12), 1465-1487. https://doi.org/10.1002/jclp.10099

Kozaric-Kovacic, D. (2008). Psychopharmacotherapy of posttraumatic stress disorder. Croatian Medical Journal, 49(4), 459-475. https://doi:10.3325/cmj.2008.4.459

Masoom Ali, S., Yildirim, M., Abdul Hussain, S., \& Vostanis, P. (2020). Self-reported mental health problems and post-traumatic growth among children in Pakistan care homes. Asia Pacific Journal of Social Work and Development, 30(1), 62-76.

Meentken, M. G., van der Mheen, M., van Beynum, I. M., Aendekerk, E. W., Legerstee, J. S., van der Ende, J., del Canho, R., Lindauer, R. J. L., Hillegers, M. H. J., Moll, H. A., Helbing, W. A., \& Utens, E. M. (2020). EMDR for children with medically related subthreshold PTSD: Short-term effects on PTSD, blood-injection-injury phobia, depression and sleep. European Journal of Psychotraumatology,11(1), 1705598. https://doi.org/10.1080/20008198.2019.1705598

Moreno-Alcázar, A., Treen, D., Valiente-Gómez, A., Sio-Eroles, A., Pérez, V., Amann, B. L., \& Radua, J. (2017). 
Efficacy of eye movement desensitization and reprocessing in children and adolescent with post-traumatic stress disorder: A meta-analysis of randomized controlled trials. Frontiers in Psychology, 8, 1750. https://doi.org/10.3389/fpsyg.2017.01750

Morris-Smith, J. \& Silvestre, M. (2013). EMDR for the next generation: Healing children and families. Academic Publishing International Limited.

Novo Navarro, N. P., Landin-Romero, R., Guardiola-Wanden-Berghe, R., Moreno-Alcazar, A., Valiente-Gomez, A., Lupo, W., Garcia, F., Fernandez, I., Perez, V., \& Amann B. L. (2018). 25 years of eye movement desensitization and reprocessing (EMDR): The EMDR therapy protocol, hypotheses of its mechanism of action and a systematic review of its efficacy in the treatment of post-traumatic stress disorder. Revista de Psiquiatria y Salud Mental, 11(2), 101-114. Doi: 10.1016/j.rpsm.2015.12.002.

Oflaz, F. (2015). Travma yaşamış çocuk ve gençlerin ele alınmasında çocuk-ergen ruh sağlığı ve psikiyatri hemşireliği uygulamaları. Türkiye Klinikleri Dergisi, 1(2), 46-51.

Özaslan, A., \& Yıldırım, M. (2021). Internalized stigma and self esteem of mothers of children diagnosed with attention deficit hyperactivity disorder. Children's Health Care, 1-13.

Özaslan, A., Yıldırım, M., Güney, E., Güzel, H. Ş., \& İşeri, E. (2021). Association between problematic internet use, quality of parent-adolescents relationship, conflicts, and mental health problems. International Journal of Mental Health and Addiction, 1-17.

Özen, Y. (2017). Psikolojik travmanın insanlık kadar eski tarihi. The Journal of Social Science, 2(1), 104-117.

Rodenburg, R., Benjamin, A., Meijer, A. M., \& Jongeneel, R. (2009). Eye movement desensitization and reprocessing in an adolescent with epilepsy and mild intellectual disability. Epilepsy \& Behavior, 16(1), 175180. https://doi.org/10.1016/j.yebeh.2009.07.015

Seidler, G. H., \& Wagner, F. E. (2006). Comparing the efficacy of EMDR and trauma-focused cognitive-behavioral therapy in the treatment of PTSD: A meta-analytic study. Psychological Medicine, 36(11), 1515-1522. https://doi.org/10.1017/S0033291706007963

Shapiro, F. (1989). Efficacy of the eye movement desensitization procedure in the treatment of traumatic memories. Journal of Traumatic Stress, 2(2), 199-223. https://doi.org/10.1002/jts.2490020207

Shapiro, F. (1999). Eye movement desensitization and reprocessing (EMDR) and the anxiety disorders: Clinical and research implications of an integrated psychotherapy treatment. Journal of Anxiety Disorders, 13(1-2), 3567. https://doi.org/10.1016/S0887-6185(98)00038-3

Shapiro, F. (2007). EMDR, adaptive information processing, and case conceptualization. Journal of EMDR Practice and Research, 1(2), 68-87. https://doi.org/10.1891/1933-3196.1.2.68

Shapiro, F. (2017). EMDR terapisi teknikleri ile acı anıları silmek (F. Gülfidan, Çev.). Kuraldış1

Shapiro, F. (2018). Eye movement desensitization and reprocessing (EMDR) therapy. Basic Principles, Protocols, and Procedures. The Guilford Press.

Shapiro, F., \& Laliotis, D. (2011). EMDR and the adaptive information processing model: Integrative treatment and case conceptualization. Clinical Social Work Journal, 39(2), 191-200. https://doi.org/10.1007/s10615-0100300-7

Shapiro, F., \& Maxfield, L. (2002). Eye movement desensitization and reprocessing (EMDR): Information processing in the treatment of trauma. Journal of Clinical Psychology, 58(8), 933-946. https://doi.org/10.1002/jclp.10068

Solomon, R. M., \& Shapiro, F. (2008). EMDR and the adaptive information processing modelpotential mechanisms of change. Journal of EMDR Practice and Research, 2(4), 315-325. https://doi.org/10.1002/9780470479216.corpsy0337

Taylor, S., Thordarson, D. S., Maxfield, L., Fedoroff, I. C., Lovell, K., \& Ogrodniczuk, J. (2003). Comparative efficacy, speed, and adverse effects of three PTSD treatments: Exposure therapy, EMDR and relaxation training. Journal of Consulting and Clinical Psychology, 71(2), 330. https://doi.org/10.1037/0022006X.71.2.330

Tolin, D. F., \& Foa, E. B. (2008). Sex differences in trauma and posttraumatic stress disorder: A quantitative review of 25 years of research. Pscyhological Bulletin, 132(6), 959-92. https://doi.org/10.1037/1942-9681.S.1.37

Valiente-Gómez, A., Moreno-Alcázar, A., Treen, D., Cedrón, C., Colom, F., Perez, V., \& Amann, B. L. (2017). EMDR beyond PTSD: A systematic literature review. Frontiers in Psychology, 8, 1668. https://doi.org/10.3389/fpsyg.2017.01668 
Van der Kolk, B. A. (2000). PTSD and the natüre of the trauma. Dialogues in Clinical Neuroscience, 2(1), 7-22. https://doi:10.31887/DCNS.2000.2.1/bvdkolk

Van der Kolk, B. A. (2006). Clinical implications of neuroscience research in PTSD. New York.

Van der Kolk, B. A., Spinazzola, J., Blaustein, M. E., Hopper, J. W., Hopper, E. K., Korn, D. L., \& Simpson, W. B. (2007). A randomized clinical trial of eye movement desensitization and reprocessing (EMDR), fluoxetine, and pill placebo in the treatment of posttraumatic stress disorder: Treatment effects and long-term maintenance. Journal of Clinical Psychiatry, 68(1), 1-11. https://doi.org/10.4088/JCP.v68n0105

Van Etten, M. L., \& Taylor, S. (1998). Comparative efficacy of treatments for post-traumatic stress disorder: A meta-analysis. Clinical Psychology \& Psychotherapy: An International Journal of Theory and Practice, 5(3), 126-144. https://doi.org/10.1002/(SICI)1099-0879

Yildirim, M. (2019). Mediating role of resilience in the relationships between fear of happiness and affect balance, satisfaction with life, and flourishing. Europe's Journal of Psychology, 15(2), 183-198. Doi: 10.5964/ejop.v15i2.1640

Yildırım, M., \& Arslan, G. (2021). A moderated mediation effect of stress-related growth and meaning in life in the association between coronavirus suffering and satisfaction with life: Development of the stress-related growth measure. Frontiers in Psychology, 12, 529.

Yıldırım, M., Iqbal, N., Khan, M. M., O’Reilly, M., \& Vostanis, P. (2020). Psychosocial needs and supports for street children in india: stakeholder perspectives: psychosocial supports for street children. International Journal of Child Development and Mental Health, 8(2), 19-28.

Yıldırım, M., \& Maltby, J. (2021a). Irrational Happiness Beliefs Scale: Development and Initial Validation. International Journal of Mental Health and Addiction, 1-14. Doi: https://doi.org/10.1007/s11469021-00513-2

Y1ldırım, M., \& Maltby, J. (2021b). Examining Irrational Happiness Beliefs within an Adaptation-Continuum Model of Personality and Coping. Journal of Rational-Emotive \& Cognitive-Behavior Therapy, 1-15. Doi: https://doi.org/10.1007/s10942-021-00405-3

Yurtsever, A., Konuk, E., Akyüz, T., Zat, Z., Tükel, F., Çetinkaya, M., Savran, C., \& Shapiro, E. (2018). An eye movement desensitization and reprocessing (EMDR) group intervention for Syrian refugees with posttraumatic stress symptoms: Results of a randomized controlled trial. Frontiers in Psychology, 9, 1-8. https://doi.org/10.3389/fpsyg.2018.00493 